\title{
Ethno Science Module: A New Direction of Environmental Education on Student Problem Solving
}

\author{
Edi Ansyah* and Ahmad Walid \\ Institut Agama Islam Negeri Bengkulu, Indonesia \\ *Corresponding author. E-mail: ediansyah@iainbkl.ac.id
}

\begin{abstract}
Indonesia is one of the countries with the greatest diversity of plants in the world. Most of the plants in Indonesia can be used as medicinal ingredients. This researcher aims to develop ethnics-based science learning modules that have the feasibility to be used after validation. Identify the types of medicinal plants found in Kali Kali Rejang Village, North Bengkulu Regency, to then be applied in the biodiversity material module. The location of sampling of medicinal plants was carried out in Kali Kali Rejang Village, North Bengkulu Regency, while the module response test was carried out in 71 elementary schools in Bengkulu City. Based on the results of the study found 15 species of medicinal plants in Kali Desa Rejang, North Bengkulu Regency, the most widely used type is Zingiberacea, which is 5 species. The results of the validation of the modules compiled obtained very valid criteria with a value of $91 \%$ from the validators and got a very good response with a value of $90.6 \%$ in the test response to 22 class V students of 71 State Primary Schools Bengkulu City. Based on these results it can be stated that the module design compiled is suitable to be used as teaching material for elementary school grade $\mathrm{V}$ grades on biodiversity material.
\end{abstract}

Keywords: Module, Ethno science, Problem-based learning, Medicinal plants, Education.

\section{INTRODUCTION}

The 2013 curriculum is a curriculum that emphasizes interactive, inspiring, fun and challenging learning. This will encourage students to be more motivated in learning and actively participating. In addition, students are given enough space to develop creativity and independence in accordance with talent, ask for, and physical development [1].

The elementary school is one of the formal institutions which have implemented the 2013 Curriculum learning gradually. The existence of a new curriculum in schools requires teachers to be more creative in teaching, learning that needs attention is learning science [2].

In elementary schools (SD), science learning is integrated in a theme. Science is a scientific product, process and attitude. Science learning can be a means for students to learn about themselves and the natural environment and apply it in their daily lives. However, a number of weaknesses of students in Indonesia were discovered, especially in the study of science, based on the results of Trends in International Mathematics and Science Study [3].

Ethno science is one of the new breakthroughs in the curriculum and characteristics of students. The word ethno science comes from the word ethno (Greek) which means nation, and scientist (Other language) means knowledge [4]. Ethno science is the knowledge possessed by a community of culture, then this science studies or studies knowledge systems and cognitive types of certain cultures, emphasis on authentic and distinctive knowledge of a cultural community. Ethno science is a study of community culture and phenomena related to nature contained in society [5].

Ethno science is a branch of cultural study that seeks to understand how natives understand their nature. Natives usually have an ideology and philosophy of life that influences them as a new form of ethnography (the new ethnography). Through ethno science, cultural research will in fact be able to develop theories of western culture that are not necessarily relevant. Local excellence is a regional characteristic that covers aspects of economy, culture, information and communication technology and ecology developed from regional potential. Potential aspects of developing local excellence include natural resources, human resources, geography, culture and history [6].

Indonesia is one of the countries with the greatest diversity of plant species. The diversity of Indonesian plants is reflected in the richness of wet tropical forests, both in the lowlands and highlands [7]. Around 30,000 plant species are estimated to be found in Indonesia's wet tropical forest, both vines, shrubs, herbs, shrubs and trees. Most types of plants in Indonesia can be used as medicinal ingredients [8]. Herbal or traditional medicine has been used by the 
people of Indonesia since ancient times and continues to grow until now. In addition to treatment, people use plants in Indonesia for health care. This need for health makes Indonesian people more inclined to prefer traditional medicine than modern medicine [9].

Traditional medicine is considered safer because it comes from herbal ingredients causing side effects that are lighter than modern medicine. Traditional medicine is also preferred because medicinal properties as raw materials for herbal medicines can be planted and obtained around the house [10].

The yard is a plot of land around the house that has many functions, one of which can be utilized by planting medicinal plants. In addition, the yard is also used for beauty, namely by planting ornamental plants Variety of medicinal plants in the yard is not only beneficial for traditional medicine, but also science, especially as teaching material [11]. Teaching materials based on the diversity of medicinal plants can play a role in building and increasing participants understanding of the material in learning in the form of module [12]. Modules are learning tools or tools that contain material that aims to enable students to learn independently or with the guidance of teachers in teaching and learning activities and ways to evaluate systematically designed to achieve goals [13].

\section{RESEARCH METHODS}

\subsection{Retrieval of Ethno science Data}

The research method is a method used by researchers to collect research data. This type of research is research and development or Research and Development ( $R$ \& D). Trianto [14] stated that research and development is a series of processes for developing new products or perfecting old products. The product is in the form of objects or hardware (hardware) and also software (software) such as books, modules, learning aids in classrooms, computer programs for data processing, libraries or laboratories, or models of education, training, guidance and systems management.

Understanding development research according to Borg \& Gall is a process used to develop and validate educational products. This research follows the steps in a cycle. The research steps or development process consists of a study of the research findings of the product to be developed, developing a product based on these findings, conducting a field trial in the setting in which the product will be used, and revising the results of the field test. The research and development steps according to Sugiyono [15] are; 1. Potential and Problems; 2. Data Collection; 3. Product Design; 4. Design Validation; 5. Design Revision; 6. Product Testing; 7. Product Revision; 8. Usage Trial.

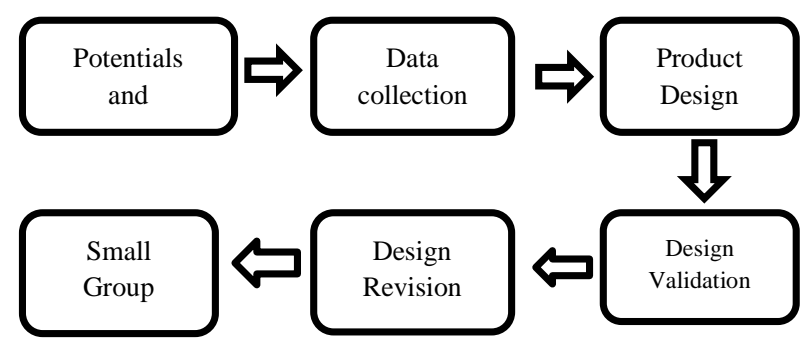

Figure 1. Research Steps Adopted from [14]

\subsection{Research Instruments}

The instrument used in this study was a module eligibility questionnaire to get validation data from 3 validators. The language validation questionnaire consisted of 15 statement components with a score of 1-5. The material validation questionnaire consisted of 16 statement components with a score of 1-5. While the media validation questionnaire consisted of 16 statement components with a score of 1-5.

\subsection{Data analysis technique}

The researcher makes a validation sheet that contains the statements. Then the validator fills out the questionnaire by giving a check mark to the category provided by the researcher based on a Likert scale consisting of 5 rating scores as follow:

Table 1. Expert Validation Rating Score

\begin{tabular}{ll}
\hline Explanation & Score \\
\hline Very good (SB) & 5 \\
\hline Good (B) & 4 \\
\hline Enough (C) & 3 \\
\hline Less (K) & 2 \\
\hline Very less (SK) & 1 \\
\hline
\end{tabular}

Furthermore, the percentage of eligibility obtained is then interpreted into categories based on the following table 2:

Table 2. Eligibility Criteria

\begin{tabular}{ll}
\hline Assessment & Interpretation Criteria \\
\hline $81 \leq P \leq 100 \%$ & Very Decent \\
\hline $61 \leq P<81 \%$ & Worthy \\
\hline $41 \leq P<61 \%$ & Enough \\
\hline $21 \leq P<41 \%$ & Not Feasible \\
\hline $0 \leq P<21 \%$ & Very Unworthy \\
\hline
\end{tabular}


Module-based teaching materials are declared theoretically feasible if the percentage of eligibility is $\geq 51 \%$.

\section{RESULTS AND DISCUSSION}

Based on the results of a study conducted on the use of medicinal plants in Kali Village, North Bengkulu Regency by interviewing village shaman, it was obtained the results of 15 species belonging to 9 families. The five families of medicinal plants that are most widely used as medicinal plants in Kali Village are Lamiaceae, Asteraceae, Acanthaceae, Euphorbiaceae and Zingiberaceae. Family with the most diversity is Zingiberace, which is 7 species. There are 5 out of 15 plants which are plants that grow in people's homes, not planted intentionally, but are also used as medicinal ingredients, namely: pudding, jambau jung, dawen salem, lajo, kunik, and spicy.

Plant organs used in medicine are roots, tubers, rhizomes, stems, leaves, flowers, fruits and seeds. The most widely used organs for treatment were 32 $(50.8 \%)$ leaves, and $7(11.1 \%)$ rhizomes and other organs. Types of medicinal plants found in Kali Bengkulu Utara Village can treat various diseases, both internal and external. One type of disease can be treated with several types of plants. The five most common types of disease use medicinal plants as medicinal ingredients namely, high blood pressure, cough, stomach ache, colds.

The results of the study of identification of medicinal plants in Kali Village, North Bengkulu Regency were developed into teaching materials in the form of modules for Biology Diversity class $\mathrm{V}$ in State Elementary School 71. The modules developed were validated to see their eligibility to the validator, the overall module design was considered to be very valid by the validator, which meant the module was feasible used in learning with an average percentage value of $91 \%$.

Table 3. Results of Validation Module for Medicinal Plant Identification in Kali Desa, North Bengkulu Regency by validator

\begin{tabular}{cccc}
\hline No & Validator & Percentage & Criteria \\
\hline 1. & Validator I & $97 \%$ & Very Valid \\
\hline 2. & Validator II & $89 \%$ & Very Valid \\
\hline 3. & Validator III & $88 \%$ & Very Valid \\
\hline \multicolumn{2}{c}{ Average Percentage } & $91 \%$ & Very Valid \\
\hline
\end{tabular}

Based on the suggestions and directions from the two validators, a revision of the Module design was carried out before the Module proceeded to the student's response test. Some suggestions and improvements of the two validators are as follows:

\begin{tabular}{ll}
\hline Assessment & Interpretation Criteria \\
\hline $81 \leq P \leq 100 \%$ & Very Decent \\
\hline $61 \leq P<81 \%$ & Worthy \\
\hline $41 \leq P<61 \%$ & Enough \\
\hline $21 \leq P<41 \%$ & Not Feasible \\
\hline $0 \leq P<21 \%$ & Very Unworthy \\
\hline
\end{tabular}

1. Use image pointer sentences

2. Present the material about preservation

3. The table is too long to show in landscape

4. Display image source

5. Do not stack on the cover image of the plant

Medicinal plants in Kali Village, North Bengkulu Regency are used as medicinal ingredients covering all parts of the plant or certain parts. The most part of plant organs used as medicinal material is $32(50.8 \%)$ in the leaves and the least is $1(1.6 \%)$ tubers. Medicinal plants can be used to treat various types of diseases, both external and internal diseases. One type of disease can be treated using several different types of plants. Disease that can be treated using many plants in this study is high blood pressure. This disease can be treated with 9 types of plants.

In the research of [9], the types of diseases that used the most medicinal plants were 13 joint plants. The high type of plant used for the treatment of a disease is thought to be influenced by many things, one of which is work. Respondents' work in [9] research is farmers, and diseases that attack are joint diseases such as gout, aches and rheumatism. Whereas in this research, the treatment using many types of plants, namely high blood pressure, is thought to be influenced by lifestyle and eating patterns that can increase blood pressure levels, one of which is smoking, consuming sweet drinks and salty foods. Many people plant plants that can be used to treat high blood pressure also because these plants can also be used to treat other types of diseases. One medicinal plant can have two or more benefits. So that the types of plants that have the ability to cure the disease are developed by the community because they adjust their needs.

The development of modules from the results of research on identification of medicinal plants in Kali Village, North Bengkulu Regency can be used as teaching materials for Class $\mathrm{V}$ natural sciences because they have passed the validation and students' response test. This shows that the module that has been developed already meets the criteria and is suitable for use as teaching material in the learning process. The results of validation by three validators with an average percentage of $91 \%$ were valid. The 
module was validated before it was declared feasible to have gone through several improvements. Improvements made based on suggestions and input from the validator. The suggestions given by the validator for the improvement of the module are, the use of pointer sentences in the picture, exposure to material about preservation, layout of tables and sources in the picture. Modifications are made to the module and then declared valid by the validator.

Then the response test was conducted by students of class V of Bengkulu 71 Primary School. The results of students' responses to the Module also fall into the "Very Good" category where the average percentage score is $90.6 \%$. This is in accordance with the criteria table for the percentage of ideality of the response test if a score of $>80 \%$ is obtained; it is included in the "Very Good" category. In the questionnaire responses of students there are 13 aspects, of the 13 aspects there are two aspects that get a low percentage score, but still in a good category. That aspect is, the use of the language used in the module gets a score of $79.2 \%$ and the second aspect of the questions contained in the module gets a score of $66.7 \%$. However, the questionnaire responses of students did not indicate which parts of the language and also questions that are difficult to understand. The low score for this aspect is thought to be due to differences in the level of understanding of the students themselves. In the aspect of language use and questions even though they scored low, they are still in the good category where the number of students who understand the use of language and also the questions in the module are still more than this module gets a very good response with an average percentage of $90.6 \%$ although there are two aspects that get a low score. This is supported by other aspects, which in other aspects score above $80 \%$.

\section{CONCLUSION}

Types of medicinal plants utilized by the people of the Rejang tribe of North Bengkulu Regency are 15 types of medicinal plants belonging to 9 families. The most widely used family is Zingiberaceae. Module eligibility level based on validation by the validator obtains results with a percentage of $91 \%$ with a very valid category and the response test by students shows an overall percentage of $90.6 \%$ which means the Module is rated very well.

\section{REFERENCES}

[1] Ahmadi, Y. (2019). Bahan Ajar Ipa Berbasis Etnosains Tema Pemanasan Global Untuk Peserta Didik Smp Kelas VII. Unnes Physics Education Journal 8 (1) .

[2] Ariningtyas, A., Sri, W., \& Widhi, M. (2017). Efektivitas Lembar Kerja Siswa Bermuatan
Etnosains Materi Hidrolisis Garamuntuk Meningkatkan Literasi Sains Siswa SMA. Journal of Innovative Science Education 2 (2).

[3] Arikunto, S. (2002). Prosedur Penelitian Suatu Pendekatan Praktek. Jakarta: Rineka Cipta.

[4] Arlitasari, O., Arlitasari, R. B., \& Pujayanto. (2013). pengembangan bahan ajar IPA Terpadu Berbasis Saling Temas dangan Tema Biomassa sumber energy terbarukan. jurnal pendidikan Fisika, 1 (1).

[5] Atmojo, S.E., (2012). Profil Keterampilan Proses Sains Dan Apresiasi Siswa Terhadap Profesy Pengrajinan Tempe Dalam Pembelajaran Ipa Berpendekatan Etnosains. JPII, Vol1 (2): 115-122.

[6] Depdiknas. (2008). Panduan Pengembangan Bahan Ajar, Jakarta: Direktorat Pembinaan Sekolah Menengah Atas.

[7] Dewi, A. P., Sarwanto., \& Prayitno, B. A. (2014). Pengembangan Modul IPA Terpadu Untuk SMP/MTS Berbasis Eksperimen Pada Tema Fotosintesis Untuk Memberdayakan Keterampilan Proses Sains. Jurnal Inkuiri. ISSN. Vol. 3 (III): 30-40.

[8] Ediansyah, E., Kurniawan, D. A., Perdana, R., \& Salamah, S. (2019). Using Problem-Based Learning in College: Mastery Concepts Subject Statistical Research and Motivation. International Journal of Evaluation and Research in Education, 8(3), 446-454.

[9] Handayani, A. (2015). Pemanfaatan Tumbuhan Berkahsiat Obat Oleh Masyarakat Sekitar Cagar Alam Gunung Simpang, Jawa Barat. Prosiding Seminar Nasional Masyarakat Biodiversitas Indonesia, 1(6):1425-1432.

[10] Hasanah, U., Dewi, N. R, dan Parmin (2013). Pengembangan Bahan Ajar IPA Terpadu Berbasis SALINGTEMAS Pada Tema Energi. USEJ. ISSN2252-6609. Vol. 2 (2). 295-301.

[11] Hobri. (2010). Metodologi Penelitian Pengembangan. Jember: Pena Salsabila

[12] Joseph, M. R. (2010). Etnhoscience and problem of method in the social scientific study of religion. Oxfordjournal. 39(3): 241-249.

[13] Juariah, Y. Y., \& Djufri. (2014). Pembelajaran Berbasis Lingkungan untuk Meningkatkan Hasil Belajar Siswa Pada Konsep Keanekaragaman Spermatophyta.Jurnal Biologi Edukasi, 6(2), 8388.

[14] Trianto. (2011). Model Pembelajaran Terpadu. Konsep, Strategi, dan Implementasinya dalam kurikulum Tingkat Satuan Pendidikan (KTSP). Jakarta: Bumi Aksara.

[15] Sugiyono, (2011). Metode Penelitian Pendidikan Kuantitatif,Kualitatif, dan R\&D. Bandung: Alfabeta. 